\title{
selenium and Cabbage and Colon Carcinogenesis in Mice ${ }^{1}$
}

\author{
Norman J. Temple ${ }^{2}$ and Tapan K. Basu $2,3,4$
}

ABSTRACT-The influence of dietary selenium and cabbage on the formation of colon tumors in female Swiss mice treated with 1.2-dimethylhydrazine [(DMH) CAS: 540-73-8] was reported. Mice recived a control diet (laboratory chow), the control diet plus solenium in the drinking water ( $1 \mathrm{mg} / \mathrm{liter}$ ), or the control diet with added cabbage $(12.8 \mathrm{~g} / 100 \mathrm{~g}$ diet). They also received 8 weekly sc injections of DMH. The experiment was divided into two time periods: $a)$ from 5 weeks before the first injection until 3 days after the last one (initiation period), and $b$ ) the subsequent 19.5 weeks until sacrifice of the mice (promotion period). Selenium had a strong protective effect when given during the initiation period; adenomas were reduced to a much greater extent than adenocarcinomas. The only effect of selenium supplementation in the promotion period was a small decrease in adenomas. Cabbage apparently had two cpposing actions. It increased tumor incidence, particularly adenocarcinomas, if given in the initiation period, but it reduced adenonla formation considerably when given in the promotion period. $-J N C l$ 1987; 79:1131-1134.

A finding that emerged from several case-control studies is that colon cancer patients have a low intake of cabbage and other cruciferous vegetables $(I-3)$. Experiments on rodent liver and intestine indicate that these foods are effective by inducing xenobiotic-metabolizing enzymes such as benzpyrene hydroxylase and aryl hydrocarbon hydroxylase $(4-7)$.

On the basis of these findings, Temple and El-Khatib (8) tested whether cabbage provides protection against DMH-induced colon carcinogenesis in mice. Although differences were not significant, cabbage tended to increase colon tumor formation in females though not in males. There are at least two possible explanations, apart from chance, for these surprising results. First, the stock diet was Purina Rodent Chow. This contains alfalfa, which resembles cruciferous vegetables as an inducer of xenobiotic-metabolizing enzymes (5-7). Thus the cabbage may have been without additional effect. Second, the enzymes induced by cabbage might actually enhance the carcinogenicity of DMH.

Several lines of evidence strongly indicate that selenium is also protective against cancer. Thus epidemiologic studies have revealed an inverse relationship between selenium intake and several major cancers (including of the colon) (9). Furthermore, cancer patients often have a history of a low-serum selenium level (9). Of 37 animal studies recently reviewed, two-thirds reported that supplementary selenium caused a reduction in lumor incidence of at least $35 \%(9)$. The rat colon is one of the tumor models for which this has been well established (10-15). With carcinogen-induced mammary tumors in rats and mice, it appears that selenium is protective at several stages of carcinogenesis but particularly during early promotion (16). However, its stage of effectiveness for colon carcinogenesis is unknown.
The present study was undertaken to investigate the effects of cabbage and selenium on colon tumor formation in DMH-treated mice. To identify the stages at which they are effective, we fed these dietary components during either the initiation or promotion periods.

\section{MATERIALS AND METHODS}

Mice and treatment.-Fernale swiss (ICR) mice were used from a colony maintained in the university animal facilities. They were housed in a temperature-controlled room with a 12-hour light-dark cycle. At an age of 5-7 weeks they were placed on the experimental diets (mean weight, $\mathrm{g}, \pm \mathrm{SD}: 21.8 \pm 2.2$ ). After being fed these diets for 5 weeks, the mice were given 8 weekly sc injections of DMH (CAS: 540-73-8; Sigma Chemical Co., St. Louis, Mo.). This was dissolved in $1 \mathrm{mM}$ EDTA and neutralized with saturated sodium bicarbonate. The first dose was $17 \mathrm{mg} \mathrm{DMH} \cdot \mathrm{diHCl} / \mathrm{kg}$ body weight; each successive dose was increased by $21 \%$ (total dose: $291 \mathrm{mg} / \mathrm{kg}$ ). Use of a gradually rising dose is based on the finding that mice develop tolerance to $\mathrm{DMH}$; thus the number of injections is cut while still minimizing toxic effects (17).

The following dietary treatments were used: $a$ ) Control diet: $98.1 \%$ Wayne Rodent Blox meal (Continental Grain Co., Chicago, IL) and $1.9 \%$ corn oil. Wayne meal consists mainly of cereal and vegetable foods (but no alfalfa) and contains (dry weight basis) $24 \%$ protein, $3.6 \%$ crude fiber, $4.1 \%$ fat, $0.15 \mathrm{mg}$ selenium $/ \mathrm{kg}$, and an adequate concentration of all nutrients. Metabolizable energy is $2,970 \mathrm{kcal} / \mathrm{kg}$.

b) Cabbage diet: $12.8 \%$ cabbage, 85.5 Wayne Rodent Blox meal, and $1.6 \%$ corn oil. The cabbage was purchased locally and homogenized in tap water by means of a blender.

Both diets were prepared by mixing the ingredients with water (total of 1 liter $/ \mathrm{kg}$ chow), and the food was

ABBREVLATIONS USED: BOP $=N$-nitrosobis(2-oxopropyl)amine; $\mathrm{DMH}=$ 1,2-dimethylhydrazine; $\mathrm{PAH}=$ polycyclic aromatic hydrocarbon.

\footnotetext{
'Received January 30, 1987; accepted July 2, 1987.

${ }^{2}$ Department of Foods and Nutrition, University of Alberta, Edmonton, Canada T6G $2 \mathrm{M} 8$.

${ }^{3}$ Address reprint requests 10 Dr. Basu.

${ }^{4}$ 'The authors thank Mr. Arin Bhattacharjee (Department of Foods and Nutrition, University of Alberta) for technical assistance. We thank Mrs. Mabel Baaske and Mrs. Sandra Casovan (Department of Pathology, University Hospital, Edmonton) for histologic work and Dr. Lawrence Jewell (Department of Pathology, University Hospital, Edmonton) for advice on the interpretation of colon tumors. We also thank The Alberta Heritage Foundation for Medical Research for financial support.
} 
given in this form. Fresh food was given every 1-2 days (usually daily) from a stock prepared roughly every 5 days and stored at $5^{\circ} \mathrm{C}$.

c) Selenium: sodium selenite in drinking water, providing $1 \mathrm{mg}$ selenium/liter.

In each case food and water were provided ad libitum. Where indicated, dietary treatments were changed 3 days after the last injection.

Tumor assessment.-Mice were sacrificed 27 weeks after the first $\mathrm{DMH}$ injection. After inspecting internal organs, the colon (including the cecum) was opened and carefully examined. Suspected tumors were removed and placed in neutral buffered Formalin. They were confirmed after staining (hematoxylin and eosin) $(18,19)$. The above procedures were done by observers who were unaware as to which dietary group the samples and mice belonged. Data were analyzed by two-tailed Student's $t$-test and by Fisher's exact probability test.

\section{RESULTS}

Diel intake.-Diet intake was measured in the week before the first injection and 4 weeks after the final injection. Mice on the control diet ate $4.9 \mathrm{~g} / \mathrm{mouse}$ per day (dry weight basis). Intake of cabbage diet was $5.3 \mathrm{~g} /$ mouse per day comprising $0.68 \mathrm{~g}$ whole cabbage and 4.6 $\mathrm{g}$ other components (dry weight). Selenium-supplemented mice consumed approximately $4.2 \mathrm{ml} /$ mouse per day ( $4.2 \mu \mathrm{g}$ selenium). This increased their daily selenium intake from $0.7 \mu \mathrm{g}$ (provided by the control diet) to $4.9 \mu \mathrm{g}$.

Body weight.-Diet had no apparent effect on body weight gain during the experiment. Weights when sacrificed are shown in tables 1 and 2 . At that time the non-DMH-treated controls were heavier than the other mice $(P<.001)$. This averaged $12.2 \mathrm{~g}$ in DMH-treated mice and $19.1 \mathrm{~g}$ in non-DMH-treated mice.

Tumor data.-Tumors were almost entirely confined to the distal half of the colon, generally $1-5 \mathrm{~cm}$ from the anus, with a smaller number at the anus. Additionally, 1 was in the cecum and I was in the uterus. Diet had no apparent effect on tumor size or location. Tumors were not detected in the control group receiving no $\mathrm{DMH}$ (table 2).
When selenium was given during the initiation period, tumor incidence fell by half $(P<.025)$ and tumor multiplicity (tumors per tumor-bearing mouse) fell by $36 \%$ (table 1). The decrease in adenomas ( $76 \%$ for inci. dence, $P=.001 ; 46 \%$ for multiplicity) was much greater than for adenocarcinomas. On the other hand, the only effect of selenium supplementation during the promo. tion period was a small and nonsignificant decrease in the incidence and multiplicity of adenomas. Selenium showed only a small protective effect if given for the whole experiment.

When cabbage was fed during the initiation period, there was a modest increase in tumor incidence, par. ticularly adenocarcinomas (table 2). However, feeding it in the promotion period resulted in a drop in adenoma formation: Incidence was down $30 \%$, and multiplicity was down $50 \%(P<.05)$.

\section{DISCUSSION}

These results provide the first demonstration of the stage of effectiveness of selenium against colon tumor formation. When mice were given selenium supplementation at a relatively modest level $(1 \mathrm{mg} /$ liter drinking water) during the initiation period (i.e., before and during DMH treatment), there was a substantial drop in the incidence and multiplicity of tumors. Adenoma, rather than adenocarcinoma, was the tumor type mainis affected. Selenium supplementation during the promo. tion period (i.e., starting only after the last DMH injection) gave merely a little protection against ade nomas. Curiously, when selenium was given throughou the experiment, only a little protective effect was seen.

With carcinogen-induced mammary tumors in rats and mice, however, although the evidence is not altogether clear, selenium appears to act at several stagn with its major action being during early promotion (16)

Originally it was predicted that cabbage would prow tect mice against DMH-induced colon cancer. This was based on case-control studies of colon cancer patient $(1-3)$. The presumed mechanism is that cabbage and lated vegetables contain various indole compounds that induce xenobiotic-metabolizing enzymes and thereb)

TABLE 1.-Effect of dietary selenium on the incidence and type of colon tumors in mice treated with DMH

\begin{tabular}{|c|c|c|c|c|c|c|c|c|c|}
\hline \multicolumn{2}{|c|}{ Dietary treatment ${ }^{a}$} & \multirow{2}{*}{$\begin{array}{l}\text { No. of } \\
\text { mice }\end{array}$} & \multirow[t]{2}{*}{ Weight, $^{b} \mathrm{~g}$} & \multicolumn{3}{|c|}{$\begin{array}{l}\text { Percent of mice with colon } \\
\text { tumors-tumor incidence }{ }^{e}\end{array}$} & \multicolumn{3}{|c|}{$\begin{array}{l}\text { Colon tumors/tumor-bearing mouse- } \\
\text { tumor multiplicity }{ }^{6, e}\end{array}$} \\
\hline Initiation & Promotion & & & Total & Adenoma & Adenocarcinoma & Total & Adenoma & Adenocarcinoms \\
\hline $\begin{array}{l}\text { Control } \\
\text { Selenium } \\
\text { Control } \\
\text { Selenium }\end{array}$ & $\begin{array}{l}\text { Control } \\
\text { Control } \\
\text { Selenium } \\
\text { Selenium }\end{array}$ & $\begin{array}{l}40 \\
22 \\
24 \\
21\end{array}$ & $\begin{array}{l}35.2 \pm 6.1 \\
34.0 \pm 4.4 \\
33.3 \pm 4.7 \\
34.5 \pm 4.5\end{array}$ & $\begin{array}{l}65.0 \\
31.8^{d} \\
62.5 \\
57.1\end{array}$ & $\begin{array}{l}57.5 \\
13.6^{e} \\
50.0 \\
42.9\end{array}$ & $\begin{array}{l}32.5 \\
22.7 \\
33.3 \\
38.1\end{array}$ & $\begin{array}{l}2.69 \pm 3.00 \\
1.71 \pm 1.50 \\
2.27 \pm 2.79 \\
2.58 \pm 1.98\end{array}$ & $\begin{array}{l}1.85 \pm 1.93 \\
1.00 \pm 1.53 \\
1.47 \pm 1.73 \\
1.42 \pm 1.51\end{array}$ & $\begin{array}{l}0.85 \pm 1.29 \\
0.71 \pm 0.49 \\
0.80 \pm 1.26 \\
1.17 \pm 1.11\end{array}$ \\
\hline
\end{tabular}

${ }^{a}$ Mice received the control diet or the control diet plus selenium. The indicated dietary treatments were given from 5 wk before the firt DMH injection until 3 days after the last one (initiation) or for the following 19.5 wk until sacrifice of the mice (promotion period).

${ }^{b}$ Values are means $\pm \mathrm{SD}$.

c For statistical analysis of tumor data, comparisons were made only with the unsupplemented control group.

${ }^{d}$ Significantly different by $F$ isher's exact probability test, $P<.025$.

'Significantly different by Fisher's exact probability test, $P=.001$. 
TABLE 2.-Effect of dietary cabbage on the incidence and type of colon tumors in mice treated with DMIH

\begin{tabular}{|c|c|c|c|c|c|c|c|c|c|}
\hline \multicolumn{2}{|c|}{ Dietary treatment } & \multirow{2}{*}{$\begin{array}{c}\text { No. of } \\
\text { mice }\end{array}$} & \multirow{2}{*}{ Weight, $g$} & \multicolumn{3}{|c|}{$\begin{array}{l}\text { Percent of mice with colon } \\
\text { tumors-tumor incidence }\end{array}$} & \multicolumn{3}{|c|}{$\begin{array}{c}\text { Colon tumors/tumor bearing mouse- } \\
\text { tumor multiplicity }\end{array}$} \\
\hline Initiation & Promotion & & & Total & Adenoma & Adenocarcinoma & Total & Adenoma & Adenocarcinoma \\
\hline $\begin{array}{l}\text { Control } \\
\text { Cabbage } \\
\text { Control } \\
\text { Cabbage } \\
\text { Control }\end{array}$ & $\begin{array}{l}\text { Control } \\
\text { Control } \\
\text { Cabbage } \\
\text { Cabbage } \\
\text { Control }\end{array}$ & $\begin{array}{r}40 \\
25 \\
20 \\
22 \\
7\end{array}$ & $\begin{array}{l}35.2 \pm 6.1 \\
32.7 \pm 3.9 \\
33.8 \pm 3.4 \\
33.3 \pm 4.1 \\
41.3 \pm 5.3^{d}\end{array}$ & $\begin{array}{c}65.0 \\
80.0 \\
60.0 \\
54.5 \\
0\end{array}$ & $\begin{array}{c}57.5 \\
68.0 \\
40.0 \\
45.5 \\
0\end{array}$ & $\begin{array}{c}32.5 \\
48.0 \\
35.0 \\
40.9 \\
0\end{array}$ & $\begin{array}{c}2.69 \pm 3.00 \\
3.15 \pm 2.60 \\
1.67 \pm 0.98 \\
3.42 \pm 2.35 \\
-\end{array}$ & $\begin{array}{c}1.85 \pm 1.93 \\
2.00 \pm 1.59 \\
0.92 \pm 0.79^{b} \\
2.00 \pm 1.48 \\
\end{array}$ & $\begin{array}{c}0.85 \pm 1.29 \\
1.15 \pm 1.23 \\
0.75 \pm 0.75 \\
1.42 \pm 1.08 \\
\end{array}$ \\
\hline
\end{tabular}

a Mice received the control diet alone or with cabbage. Other details are as in table 1 , footnotes $a, b$, and $c$.

'Significantly different by Student's $t$-test, $P<.05$.

-Non-DMH-treated control group.

¿Significantly different from other mice combined by Student's $t$-test, $P<.001$.

direct carcinogens toward a detoxification pathway $(4-7$, 20).

In this study we used a level of cabbage comparable to that in human diets $(12.8 \mathrm{~g} / 100 \mathrm{~g}$ diet, equivalent to $118 \mathrm{~g} / 2,500 \mathrm{kcal})$. It appears that cabbage has two dis. tinct effects. Feeding it in the initiation period modestly increased tumor incidence, particularly adenocarcinomas. When fed during the promotion period, incidence and multiplicity of adenomas fell. This antipromotion action may reflect the reportedly strong cation-exchange capacity of cabbage fiber (2l).

The apparent enhancement of carcinogenesis after feeding cabbage during the initiation period resembles other experiments on DMH-treated animals. Temple and El-Khatib (8) observed that feeding cabbage to mice throughout the experiment tended to increase colon tumor formation. Pence et al. (22) recently studied indole-3-carbinol, an inducer of xenobiotic metabolizing enzymes and one of the compounds thought to explain the supposed anticarcinogenic action of cabbage. Feeding it increascd adenocarcinoma formation in the rat intestine (mainly colon). Similarly, Srisangnam et al. (23) observed that cabbage tended to increase tumor yield in mice. However, in their experiment the tumors were not in the colon but mainly in the spermatic cord followed by the liver and kidney. Cabbage has also been reported to increase the incidence of pancreatic carcinoma in hamsters treated with BOP (24).

In contrast to the above findings when the carcinogen is a PAH, a protective effect has been observed. Thus indole-3-carbinol and related compounds protected rats against mammary tumors induced by 7,12-dimethylbenz[ $a$ ]anthracene and tumors of the forestomach induced by benzo $[a]$ pyrene $(25)$.

How are these seemingly contradictory results to be explained? It is likely that cabbage and its active ingredients consistently induce xenobiotic metabolizing enzymes. In some cases, such as DMH and BOP, this enhances the production of the ultimate carcinogen, whereas with PAH the reverse is true. Since cabbage and other cruciferous vegetables are apparently protective against human colon cancer, this indicates that the carcinogen responsible has a metabolism (and a chemical structure?) resembling PAH rather than DMH or
BOP. This indication suggests a probable avenue of further research.

\section{REFERENCES}

(I) Grahim S, Mffthin C. Diet and colon cancer. Am J Epidemiol 1979; 109:1-20.

(2) HAENSZEL IW, LOCKE FB, SEGI M. A case-control study of large bowel cancer in Japan. JNCI 1980; 64:17-22.

(3) Mlanousos O, DaY NE, Tricrtopoulos D, et al. Diet and colorectal cancer: A case-control study in Greece. Int J Cancer 1983; 32:1-5.

(f) PANTuCK EJ, Hsuo K-C, Lous WD, et al. Stimulatory effect of vegetables on intestinal drug metabolism in the rat. $J$ Pharmacol Exp Ther 1976; 198:278-283.

(5) Bradfield CA, Chang Y, BJeldanes LF. Elfccts of commonly consumed vegetables on hepatic xenobiotic-metabolizing enzymes in the mouse. Food Chem Toxicol 1985; 23:899-904.

(6) SALBE AD, Bjeldanes LF. The effecis of dietary Brussels sprouts and Schizandra chinensis on the xenobiotic-metabolizing en. zymes of the rat small intestine. Food Chem Toxicol 1985; 23:57-65.

(7) WATtenberc LIV. Studies of polycyclic hydrocarbon hydroxylases of the intestine possibly related to cancer. Effect of diet on benzpyrene hydroxylase activity. Cancer 1971; 28:99-102.

(8) Temple NJ, El-Khntib SM. Cabbage and vitamin E: Their effect on colon tumor formation in mice. Cancer Lett. In press.

(9) Combs GF, CLark L.C. Can dietary selenium modify cancer risk? Nutr Rev 1985; 43:325-331.

(10) BIRT DF, LAwSON TA, Jutius AD, et al. Inhibition by dietary selenium of colon cancer induced in the rat by bis(2-0xopropyl)nitrosamine. Cancer Res 1982; 42:4455-4459.

(II) ReDDY BS, TANAkA T, El.BAyount $k$. Inhibitory eflect of diecary $p$-methoxybenzeneselenol on azoxymethane-induced colon and kidney carcinogenesis in temale F344 rats. JNCI 1985; 74:1325-1328.

(12) JACOBs MM. Selenium inhibition of 1,2-dimethylhydrazine induced colon carcinogenesis. Cancer Res 1983; 49:1616-1619.

(13) - Inhibitory effects of selenium on 1,2-dimethylhydrazine and methylazoxymethanol colon carcinogenesis. Correlative studies on selenium effects on the mutagenicity and sister chromatid exchange rates of selected carcinogens. Cancer Lett 1977; 40:2556-2561.

(14) Jicons MiM, Jinsson B, Griffin AC. Inhibitory effects of selenium on 1,2-dimethylhydrazine and methylazoxymethanol acetate induction of colon tumors. Cancer Lett 1977; 2:133-138.

(15) Soullier BK, WILSON PS, Nigro ND. Effect of selenium on azoxymethane-induced intestinal cancer in rats fed high fat diel. Cancer Letl 1981; 12:343-348.

(16) Vernit LN. Selenium in carcinogenesis. Biochim Biophys Acta 1984; 738:203-217.

(17) Temple NJ, El-Khitib SM. Toxicity of 1,2-dimethylhydrazine 


\section{Temple and Basu}

in mice: Effect of diet and development of tolerance. J Food Salety 1985; 7:77-81.

(18) Robsins SH, Cotran RS, Kumar V. Pathologic basis of discase New York: Saunders, 1984:218-220.

(19) MAdara JL, Harte P, Deasy J, et al. Evidence for an adenomacarcinoma sequence in dimethylhydrazine-induced neoplasms of rat intestinal epithelium. Am J Pathol 1983; 110:230-235.

(20) Loub WD, WaTtenberg LIV, Davis DIV. Aryl hydrocarbon hydroxylase induction in rat tissues by naturally occurring indoles of cruciferous plants. J Natl Cancer Inst 1975; 54: 985-988.

(2I) MCCoNinell AA, EASTwoon MA, Mitchiell WVD. Physical characteristics of vegetable foodstuffs that could influence bowel function. J Sci Food Agric 1974; 25:1457-1464.

(22) Pence BC, Bunningh F, Yang SP. Multiple dietary factors in the enhancement of dimethylhydrazine carcinogenesis: Main efley of indole-3-carbinol. JNCI 1986; 77:269-276.

(23) SRISangnam C, Hendricks DG, Sharma RP, et al. Effects of die. tary cabbage (Brassica oleracea L.) on the tumorigenicity 1,2-dimethylhydrazine in mice. J Food Safety 1980; 4:235-245.

(24) BirT DF, TibBeis MG, POUR PM. Enhancement of pancreatic carcinogenesis in Syrian hamsters fed dried cabbage in a high fat diet. Fed Proc 1986; 45:1076.

(25) WATTENBERG LW, LOUB WD. Inhibition of polycyclic aromatic hydrocarbon-induced neoplasia by naturally occurring indoles. Cancer Res 1978; 38:1410-1413. 